\title{
A condicionante exógena e a homogeneização cultural: reflexões sobre a formação do cânone em Moçambique
}

Vanessa Riambau Pinheiro ${ }^{a}$

\begin{abstract}
Resumo
O propósito desta pesquisa é problematizar a formação do cânone literário em Moçambique, investigando que processos concorrem para sua constituição e de que lugar teórico opinam os críticos que o determinam. Após discorrer sobre estas questões - quem define o cânone e em que fatores se baseia -, procuraremos analisar instâncias específicas relativas à constituição da moçambicanidade como elemento de consolidação literária interna. Dentre elas, verificaremos a recorrência de temáticas de cunho essencialista e a consequente representação de uma pseudo homogeneização cultural praticada no país africano. A fim de respaldar nosso estudo, nos apoiaremos nos estudos teóricos de Appiah (1997), Bhabha (1998), Mbembe (2014), Anderson (2008), Leite (2012, 2014) e Martinho (2001), entre outros.
\end{abstract}

Palavras-chave: Cânone; Literatura; Moçambique. 
Uma das criações mais representativas da colonização moderna é exatamente a literatura colonial.

(NOA, 2002).

\section{A formação do cânone}

\subsection{Fatores exógenos}

A fim de começar a problematização acerca da formação do cânone literário em Moçambique, é mister refletir sobre duas questões: 1. Quem o define? 2. A partir de que critérios? Ou ainda: que tipo de grupos, ou de interesses, estão representados nos cânones?

Segundo a estudiosa Ana Maria Mão-de-Ferro Martinho, "O cânone tem origem fundamental na tradição bíblica e detém o valor de ser suporte de verdades." (2001, p.447). É notória a arbitrariedade do cânone: como toda convenção, presta-se a determinado fim. Em sua fundamentação, não se buscam perspectivas interculturais ou pluralizantes. "De base essencialista, o cânone não se funda verdadeiramente numa dimensão de alteridade ou de construtivismo, mas na visão de uma norma centrada na definição de critérios sociais e colectivos." (MARTINHO, 2001, p.441).

Se tomarmos como verdade o pressuposto de que a literatura constitui-se a partir da representação da sociedade, tal qual nos afirma o conceito aristotélico de mímesis, podemos inferir que o cânone pretende fixar valores considerados representativos de determinada época histórica e/ou cultural, buscando estabelecer uma relação de identificação com determinado país que o representa. Para que esta relação seja estabelecida, entretanto, é necessário que os textos situados na mesma perspectiva diacrônica sejam afins, coadunem-se de tal forma que sua bacia semântica possa ser reconhecida como paritária e homogênea. Tal fator é ainda mais determinante ao se tratar das literaturas pós-coloniais ou pós-europeias ${ }^{1}$ : por serem relativamente recentes - boa parte delas tem pouco mais de cem anos -, encontram-se ainda em fase de consolidação e carecem de ícones que as legitimem face ao mundo externo. Entretanto, a quem interessa e como se processa essa 
2 O escritor Lucílio Manjate (2017) afirma, em entrevista concedida à autora deste estudo: "A distribuição é um cancro! Nós publicamos livros em Maputo. Por ser a capital, acaba sendo o centro de tudo. O autor moçambicano não se importa em publicar em Maputo em não sair e não ir fazer olançamento na Beira, em Nampula."

3 Martinho (2001, p.47) afirma que a literatura africana é sobretudo criticada e comentada de fora. E destaca: "o que nos faz, críticos europeus, cair no contra-senso de uma leitura que quase não tem sustentação paritária local." legitimação externa?A nigeriana Amina Mama (2010, p.532) constata: a maior parte do que é recebido como conhecimento acerca de África é produzido no Ocidente.

A estudiosa Ana Mafalda Leite (2013), à parte de responder estas questões, suscita outras que lhe são complementares. Ao questionar de que lugar teórico escreve a crítica e quais são os fatores a serem considerados quando se julga a atribuição de mérito ou de desadequação canônica, considera:

Essa questão implica outras que merecem estudo, como as estratégias de edição, difusão, quem lê, quem julga e aprecia. Tome-se como exemplo a maior ou menos dependência em relação aos centros culturais e editoriais das ex-metrópoles, os posicionamentos mais ou menos essencialistas do exercício da prática crítica, e confrontamo-nos com importantes questões sobre os critérios de avaliação da "literaridade". (LEITE, 2013, p. 26)

O mercado externo, nomeadamente Portugal e Brasil, são os principais consumidores da literatura africana de expressão portuguesa. Destarte, instauram-se as seguintes questões: o consumo externo da literatura africana determina a produção dos escritores ou seria o contrário? Ou ainda: que critérios são levados em conta para a promoção de determinados autores em detrimento de outros?

Se tomarmos a literatura moçambicana como exemplo, poderemos compreender como se processa essa dinâmica de dependência exógena: a maioria das poucas livrarias concentrase na capital Maputo,o país tem poucas editoras, além de não ter adequada distribuição ${ }^{2}$ de livros. Não havendo força no mercado editorial interno nem distribuição, não existem condições de se criar uma dinâmica editorial mobilizadora em Moçambique. Fomenta-se, desta forma, a retroalimentação exógena: os autores publicam no exterior, são criticados internacionalmente ${ }^{3}$ e divulgados fora de seu país de origem. Esta situação é conhecida pelos escritores locais que, quando podem, publicam fora, alegando dificuldade de publicar em Moçambique.

Entretanto, ainda assim são poucos os autores moçambicanos que conseguem transpor as fronteiras. As razões podem relacionar-se com as estratégias midiáticas editoriais - que priorizam alguns escritores em detrimento de 
4 Ainda de acordo com Lucílio Manjate (2017): Os nomes que são chamados pra mostrar essa questão da internacionalização são nomes que produziram, têm obra feita, tem anos de estrada. Portanto, fazer literatura é, primeiro, um compromisso com a arte, e esse compromisso requer trabalho, publicação e exposição. Portanto, para mim, a primeira questão é essa. Depois, é produzindo, e produzindo com qualidade, que todo o resto vem por arrasto. Nós dizemos, por exemplo, que a crítica não fala. Mas a crítica vai falar de que se não estamos a produzir? A crítica vai lançar um olhar para quem produz. Não vai lançar um olhar para um autor que em dez anos publicou apenas um livro. É difícil fazer isso.

5 “H á c ríticos moçambicanos que se pronunciam, palestras em lançamentos de livros, apresentações desses livros, nós temos isso. O que nos falta, penso, é a publicação desses textos de forma mais ou menos sistematizadas, compilar os textos e publicá-los. Esse é um dos grandes problemas." (MANJATE, 2017).

6 Países africanos de língua oficial portuguesa.

7 Como tradicional, consideramos a seguinte acepção: “As tradições são entendidas enquanto narrativas da memória colectiva, sofrendo as influências do fito a que obedecem, seja do meio onde ajudam a organizar as relações sociais, seja de instâncias de pendor hegemónico como o Estado e respectivo aparato ideológico e propagandístico." ( N A S C I M E N T O ; ROCHA, 2013, p.31). outros -, além do pouco empenho e frequência de publicação ${ }^{4}$ de certos autores e da falta de sistematização ${ }^{5}$ da crítica interna.

Nomeadamente, os autores moçambicanos mais publicados externamente são Mia Couto e Paulina Chiziane. Aplica-se, portanto, a lógica do mercado: publicam-se autores considerados vendáveis. A literatura, dessa forma, tornase parte do sistema simbólico representativo do país, na medida que a máxima legitimação cultural implica em capital econômico. Neste sentido, nos alicerçamos na teoria de campo intelectual de Pierre Bourdieu (1996), nomeadamente o conceito de capital simbólico, ou seja, tudo aquilo que confere valores culturais e permite-nos identificar os agentes no espaço social. Todo ato narrativo revela conexão entre o sujeito individual e suas relações sociais, o que envolve um investimento simbólico pelo sujeito que não é completamente controlado por ele. Não podemos, outrossim, negar as implicações sociais repercutidas a partir da literatura, nem os por ela gerados.

Entretanto, quem define este capital simbólico são, principalmente, os críticos e editoras de fora do país. Talvez caiba aqui a questão formulada pelo filósofo marfinense Paulin J. Hountondji (2010, p.118): “Quão africanos são os estudos africanos?" E ainda: qual é o papel do respectivo país de origem na definição do cânone literário?

\subsection{A formação do cânone: fatores endógenos}

Segundo o estudioso ganês Anthony Appiah (1997), em seu conhecido livro A casa do meu pai, a literatura cumpre um papel fundamental no desenvolvimento da cultura nacional. No caso das literaturas dos Palop ${ }^{6}$, esta assertiva tem ainda mais fundamento, já que, ainda segundo o mesmo autor, diferentemente do projeto literário da Europa, que versa sobre a descoberta do eu, o projeto literário africano é coletivo e presta-se à funcionalidade específica de afirmação cultural. Para a realização deste projeto - de traços épicos e metafísicos -, foi preciso que os autores vissem-se engajados nesta missão de "narrar a nação" (ANDERSON, 2008) para que ela pudesse, afinal, ser imaginada.

Evidentemente, os temas ditos tradicionais ${ }^{7}$ estão inseridos em um contexto que os justificam. Nos países 
africanos de língua portuguesa, como já foi dito, a literatura tornou-se um veículo essencial para a legitimação cultural; destarte, também contribuiu para o fortalecimento dos valores ancestrais, bem como das tradições orais, ao reinventá-las e preservá-las para a posteridade através de relatos que as mencionem ou que imitem suas práticas; converteu-se também num instrumento de resistência contra o colonizador, tendo sido, além de um ato cultural, um ato político - cabe recordar que foi na Casa dos Estudantes do Império que a maior parte das ações revolucionárias foram planejadas, isso sem mencionar o papel de escritores como Amílcar Cabral e Agostinho Neto no processo descolonizatório -; por fim, promoveu a celebração da negritude e da afirmação da alteridade.

Em Moçambique, tal mobilização pela restauração da identidade e cultura nacional propagou-se mais intensamente, e contou com a participação da Frelimo. Borges (2001, p.236) afirma que "[...] os valores decadentes, as ideias erradas, o espírito de imitação cega do estrangeiro e a imoralidade eram entre as sequelas do colonialismo, as mais combatidas pela Frelimo". (Re)Encontrar ou mesmo forjar a tradição secular foi a saída encontrada para que os valores culturais, impedidos de serem disseminados por ordem de Salazar, pudessem ser reencontrados e adotados pelas novas gerações.

Com um movimento de engajamento repressor, o partido criticou a tendência, na sociedade moçambicana pós-independência, a copiar o modelo cultural estrangeiro, em especial das culturas dos países de primeiro mundo, predominantemente formado por pessoas de origem branca. Ainda de acordo com Borges (2001, p.237), a mobilização contra a alienação e descolonização mental moçambicana foi empreendida visando, principalmente, "àqueles que pertenciam à classe média, [tidos como] portadores de hábitos supérfluos e alienantes, resultados de imitação cega do estrangeiro."

Cabe destacar, portanto, que a vinculação ideológica esteve na base da constituição identitária em Moçambique nos anos pré e pós-Independência. A dita "moçambicanidade", como denominação identitária específica, deu-se enfaticamente a partir de valores intrínsecos. Mesmo um escritor que poderia ser questionado no contexto pan-africanista como Mia Couto por ser branco e filho de portugueses -, ajudou na consolidação 
8 "O paradigma desse novo cânone é representado pela colectânea de contos de Luís Bernardo HownanaNós matámos o cão tinhoso, obra de fortuna considerável desde a sua primeira edição e que ficou consagrada, nessa altura, nos programas de vários níveis de ensino." (MENDONÇA, 2011, p.18).

9 Godido foi publicado postumamente, em 1952. O autor faleceu em 1949, em Lisboa, antes da mobilização pela Independência e da formação dos partidos políticos. da identidade literária moçambicana. De acordo com Mendonça (2011, p.19), "[a discussão em torno da obra de Mia Couto] deu consistência a uma concepção de literatura assente em pressupostos essencialistas, ainda hegemônica em alguns círculos da criação e da recepção literárias." Isso só foi possível porque, ainda que não cumprisse o requisito pressuposto da raça, o escritor fazia jus a outro importante parâmetro: a questão ideológica vinculada à temática tradicional. Neste sentido, o papel da Frelimo foi fundamental. Mendonça (2011, p.17) confirma esta hipótese, ao afirmar que "o escritor só era legitimado pela práxis revolucionária."

A fim de exemplificar, vale destacar os escritoresícones ovacionados em Moçambique após a Independência, considerados representativos do cânone local: José Craveirinha e Luís Bernardo Hownana, respectivamente na poesia e na prosa. Especificamente, o livro de contos de Hownana, Nós matámos o cão tinhoso 8 (1964), é considerado o marco fundacional da prosa moderna moçambicana. Obras anteriores, como a de João Dias ${ }^{9}$, apesar de possuir conteúdo de teor social, foi posta em menor relevo face ao contexto político-ideológico da obra de Hownana. A publicação, realizada no ápice das mobilizações nacionalistas e ocorrida em plena guerra pela libertação, veio fortalecer o aparato imagético do nacionalismo, constituindo-se, à exemplo como aconteceu com Luandino Vieira com o livro Luuanda (1963), em Angola, na obra-símbolo da nova literatura nacional.

Moçambique, dessa forma, construiu seu nacionalismo a partir da ideia da identidade reificada literariamente, livre da alienação colonialista. Fortaleceu-se a imagem da pátria unificada e coletiva a fim de fortalecer a nova representação nacional o que, obviamente, promoveu aspectos da cultural local em detrimentos de outros, que foram marginalizados. $\mathrm{O}$ Estado, representado em Moçambique pela Frelimo, apostou na centralização e homogeneização para assegurar a unificação nacional. O problema é que o centralismo estatal, longe de ser equitativo, ostracizou grupos étnicos e tradições culturais locais. Em Moçambique, especificamente, o Sul foi privilegiado, por ser o campo de atuação, por excelência, da Frelimo. 


\subsection{A temática autóctone}

A literatura pós-colonial, inspirada fortemente por um cariz de reconhecimento nacional nas décadas que antecederam a Independência, ampliou-se na busca da identificação cultural. Incide, então, um irônico paradoxo: a fim de legimitar-se como autônoma frente ao mundo ocidental, uma das vias de esta produção literária objetiva resgastar elementos autóctones; entretanto, esta sociedade, ocidental e globalizada, é a principal consumidora desta literatura.

A fim de promover autorrepresentação, houve a necessidade de contemplar temáticas de cunho essencialista, o que acabou por promover o que o estudioso Francisco Noa (2002) chama de "zoomorfização", excluindo formas mais cosmopolitas e plurais de escrita em África, pensamento com o qual concordam Laranjeira (2005) e Martinho (2001). De acordo com a estudiosa, "O que nós podemos entender como generalizado é que nas sociedades africanas pós-coloniais os cânones literários se centram fundamentalmente na figura do negro e nos modos que assume a sua representação." (MARTINHO, 2001, p.447).

Segundo o crítico ganês Anthony Appiah (1997), devemos renunciar à ideia de que existe uma África mítica na qual as culturas se interrelacionam. Assim sendo, seria mister considerar cada país com suas próprias especificidades, sabendo que todos, em algum momento de sua história, farão a busca para redescobrir sua cultura e(re)inventar as tradições ${ }^{10}$.

Abiola Irele (1990), ensaísta nigeriano, ratifica esta ideia, ao afirmar que os africanos procuraram estrategicamente, desde o século XIX e principalmente a partir da descolonização, a retomada de um ethos africano, e que a tradição se tornou o tema central a ser desdobrado nessas literaturas. Evidentemente, a projeção ficcional deste ethos, que já foi arma na época da poesia de combate, agora serve de base à legitimação cultural.

Como afirma Achille Mbembe (2014), tudo nos leva a crer que exista um aparato próprio do sistema colonial que parece impor ou insinuar, mesmo aos que pretendem rechaçá-lo, a existência de um discurso preexistente que o condiciona à imitação de si próprio, ou seja, a um simulacro. Neste sentido,

${ }^{10}$ De acordo com o conceito de Hobsbawm (1984). os temas ditos autóctones não seriam, como comumente se poderia atribuir, responsáveis pela reafirmação da identidade 
africana no mundo ocidental, mas corresponderiam ao reforço desta estereotipação que se pretende evitar.Assim, para o autor, a identidade negra só pode ser problematizada enquanto "identidade em devir" (MBEMBE, 2014, p.166).

No caso específico da literatura moçambicana, Mendonça (2011) esquematiza este conflito a partir de três vertentes que, segundo a estudiosa, cronologicamente tornaram-se o cerne das temáticas literárias: ser africano e ser europeu, ser africano $x$ ser europeu, ser nacional $x$ ser universal. Talvez o quarto viés possa vir a ser "ser nacional e ser universal", encontrando-se uma forma de conciliar aspectos tradicionais com a modernidade de maneira fluida, sem incorrer no essencialismo nem na ocidentalização da literatura.

Ao atribuir aspectos de origem autóctone na base das literaturas africanas, o cânone que se estabelece firma-se como um discurso identitário definido, prioritariamente, pela sociedade ocidental. Entretanto, esta identidade também é forjada, na medida em que é uma imitação de si; outrossim, também espelha uma imagem distorcida ao mundo euroamericano $^{11}$.

Ademais de o mercado externo buscar uma representação baseada em uma vertente essencialista em África, podemos verificar, outrossim, que esta versão é parcial. Em Moçambique, por causa de questões já abordadas, como a falta de distribuição de livros e a concentração cultural em Maputo, prevalece a disseminação dos hábitos culturais do Sul do país, ignorandose a grande diferença que existe em relação as outras regiões. $\mathrm{O}$ estudioso marfinense Hountondji (2002) denuncia este aspecto reducionista, creditando a homogeneização e simplificação do complexo continente africano à incapacidade de descolonizar a vida intelectual, mesmo em África.

A escritora Paulina Chiziane é uma das poucas autoras que têm buscado resgatar a vivência cultural de outras regiões de Moçambique, como fez, por exemplo, na obra Niketche: uma história de poligamia (2001). Na trama, a partir da narração da história da protagonista Rami em convivência com as outras esposas de seu marido, os hábitos culturais do Norte aparecem em contraste com os do Sul, interagindo de maneira

11 Segundo terminologia de Mbembe (2014).

12 Conforme acepção de Bakhtin (2008). polifônica ${ }^{12}$. Entretanto, não é assim que geralmente acontece; Moçambique acaba por exportar uma versão literária de si que só contemplaa capital Maputo e seus arredores. 
O estudioso Mudimbe (2013) argumenta que os discursos sobre as realidades africanas foram gerados à margem dos seus contextos de origem, e que tanto seus eixos discursivos quanto sua linguagem têm sido limitados pela autoridade de sua exterioridade, o que lhe retira a densidade e lhe confere um cariz artificioso. Este perfil narrativo, de fácil consumo e sem hermetismos narrativos nem linguísticos, demonstra ser mais passível de receptividade por parte dos leitores. Isso explicaria, por exemplo, o fato de um escritor excepcional como Ungulani Ba Ka Khosa ter menos aceitação no mercado externo: não raro, os temas explorados por ele são pouco palatáveis e reivindicam dedicação do leitor à compreensão do contexto, já que o autor mescla o português com palavras de idiomas locais - como changana e ronga - e, geralmente, não utiliza glossários. Estes fatores dificultariam o acesso à literatura ao leitor médio não-moçambicano.

Resta-nos a questão: a condicionante exógena atua como fator de interferência ou de contribuição à formação do cânone literário moçambicano?

Leite (2013) afirma que há muitas atitudes subjacentes nas formações discursivas em relação a África. Dentre elas, destaca a de cunho paternal, com evidentes resquícios coloniais, revelando um olhar exterior que encara o outro com distância e tolerância, mas não lhe reconhecendo, de fato, maturidade e autonomia.

Entretanto, há um processo complexo envolvido na estrutura deste paternalismo pós-colonial; não podemos reduzi-lo ao mero antagonismo de partes. Concordamos com Leite (2013), que ressalta que se deve evitar uma visão dicotômica da história em África, a fim de se buscar uma perspectiva mais neutra dos factos.

\section{Entre o Outro e o Próprio}

O filósofo congolense Mudimbe (2013) afirma que o cerne da questão é que, até agora, tanto os intérpretes ocidentais quanto os analistas africanos têm usado categorias e sistemas conceptuais que dependem de uma ordem epistemológica ocidental. Mesmo nas descrições "afrocêntricas" mais evidentes, os modelos de análise referem-se, explícita ou implicitamente, consciente ou inconscientemente, à mesma ordem. 
O conflito, entretanto, revela-se à medida que se verifica que este desejo não conduz, necessariamente, à desautomatização do pensamento colonial. Imersa em temas autóctones, a literatura africana continua atraindo cada vez mais olhares externos à África. Esta versão de África transformou-se, assim, na versão legitimida exteriormente.

Aqui cabem singularidades que são necessárias explicitar: Moçambique está situado próximo de outros países, todos de língua inglesa, além de ter tido "fraca integração colonial" (CHABAL, 1994), dada a distância do país em relação as outras colônias. Além disso, sofre influência da cultura cristã, hindu e muçulmana. Estes aspectos fazem do país, por si só, um mosaico cultural por excelência. Sabemos, por dificuldades internas já referidas, que a literatura moçambicana precisa, não de uma condicionante exógena, mas certamente de uma perspectiva externa para promover-se. No entanto, como já foi discutido, por motivos vários, há a tendência da representação de uma cultura homogeneizada, o que por si só constitui uma falácia. Cabe perguntar: de que forma pode ser revertida a tendência estigmatizante sem a negação da origem do sujeito pós-colonial?

Homi Bhabha (1998), em sua clássica obra O local da cultura, também procura uma forma de reposicionar o (pós) colonizado na história moderna. Para o teórico, a saída possível seria encontrar um lugar de enunciação que procure escapar de noções essencialistas e transgredir as fronteiras culturais traçadas pelo pensamento colonial.

Segundo Nascimento e Rocha (2013, p.31), atualmente há um ambiente mais propício à diversidade cultural, reconhecendo-se a esfera da pluralidade, não mais da unicidade, como um constitutivo da identidade local das culturas postas em questão. $\mathrm{O}$ desafio da construção das literaturas pós-europeias consiste em valorizar o mosaico de identidades regionais como índice de uma rede lítero-sóciocultural complexa e diversificada que constitui um país, no qual sua heterogeneidade nunca venha a ser fator de demérito, antes revele sua pluralidade. Mendonça (2011, p.20) aponta para esta via, ao afirmar que a literatura emergente, ao mesmo tempo em que se vê inserida num contexto histórico conflituoso que lhe acentua a necessidade de afirmação identitária, encontra- 
se imersa em tendências relativistas trazidas por novas concepções de mundo "[...] tendentes a desconstruir os vínculos que a inseriam num espaço e num tempo históricos."

Como bem afirmou o escritor Lucílio Manjate, a literatura moçambicana está em vias de renovação:

Costumo brincar com os meus colegas e digo que nós temos autores de qualidade para os próximos cem anos à vontade. Estamos a falar dos jovens que são premiados, internacionalmente inclusive. E que tem mostrado trabalhos muito bons. Eu privilegio muito a literatura moçambicana quando olho para as demais literaturas. (MANJATE, 2017)

É mister, portanto, descobrir uma via de escape que permita que a vida intelectual, produzida dentro de África, venha a ser descolonizada, num trabalho que atue a partir da desestereotipação endógena a fim de influenciar a perspectiva falhada da dominante exógena. Discutir o cânone, neste sentido, é uma forma legítima de questionar este capital simbólico imposto por "[...]grupos detentores do poder cultural, que legitimaram um repertório, com um discurso, por vezes globalizante" (LEITE, 2013, p.25). É também uma maneira de se refutar a exclusão de grupos e etnias com finalidade sistematizadora e homogeneizante. Neste sentido, poderíamos, como sugere Martinho (2001, p.23), lutar por um cânone nacional moçambicano que permita registrar a complexidade de dados culturais.

\section{REFERÊNCIAS}

ANDERSON, B. Comunidades imaginadas: reflexões sobre a origem e a difusão do nacionalismo. São Paulo: Companhia das Letras, 2008.

APPIAH, K. A. Na casa do meu pai: a África na filosofia da cultura. Rio de Janeiro: Contraponto, 1997.

BAKHTIN, M. Problemas da poética de Dostoiévski. Trad. Paulo Bezerra. 4. ed. Rio de Janeiro: Forense Universitária, 2008.

BHABHA, H. K. O local da cultura. Belo Horizonte: Ed. da UFMG, 1998.

BORGES, E. A política cultural em Moçambique após a Independência (1975-1982). In: FRYE, P. (Org.). Moçambique: ensaios. Rio de Janeiro: Ed. da UFRJ, 2001. p.225-242. 
BOURDIEU, P. Espaço social e espaço simbólico. In:

Razões práticas. Sobre a teoria da ação. Campinas, SP: Papirus, 1996, p.12-24.

CHIZIANE, P. Niketche: uma história de poligamia. São Paulo: Companhia das Letras, 2001

DIAS, J. Godido e outros contos. Lisboa: Sol, 2014.

CHABAL, P. Vozes Moçambicanas: literatura e nacionalidade. Porto: Veja, 1994.

HOBSBAWM, E. A invenção das tradições. Rio de Janeiro: Paz e Terra, 1984.

HOUNTONDJI, P.J. Conhecimento de África, conhecimentos de africanos: duas perspectivas sobre os estudos africanos. In: SANTOS, B.; MENESES, M. P. Epistemologias do Sul. Coimbra: Edições Almedina, 2010. p.117-130.

. The Struggle for Meaning: Reflections on Philosophy, Culture and Democracy in Africa.Athens: Ohio University Press, 2002.

HOWNANA, L.B. Nós matamos o cão tinhoso. Lisboa: Cotovia, 2014. IRELE, A. The African Experience in Literature and Ideology. Bloomington: Indiana University Press, 1990.

LARANJEIRA, J. Ensaios Afro-Literários. 2. ed. Lisboa: Novo Imbondeiro, 2005.

LEITE, A. M. Ensaios sobre literaturas africanas. Moçambique: Alcance Editores, 2012.

Colibri, 2014.

Literaturas africanas e formulações pós-coloniais. Lisboa:

Nação e Narrativa Pós-Colonial II: Angola e Moçambique

- Entrevistas. Lisboa: Colibri, 2013.

MAMA, A. Será ético estudar África? Considerações preliminares sobre pesquisa académica e liberdade. In: SANTOS, B.; MENESES, M. P. Epistemologias do Sul. 3. ed. Coimbra: Edições Almedina, 2010. p. 529-560.

MARTINHO, A. M. Cânones literários e educação: os casos angolano e moçambicano. Lisboa: Fundação CalousteGulbenkian, 2001. MBEMBE, A. Crítica da razão negra. Lisboa: Antígona, 2014. MENDONÇA, F. Literatura moçambicana nas dobras da escrita. Maputo: Ndjira, 2011. 
MUDIMBE, V.Y. A invenção da África: gnose, filosofia e ordem do conhecimento. Angola: Edições Mulemba; Portugal: Edições Pedago, 2013.

NASCIMENTO, A.; ROCHA, A. (Orgs.). Em torno dos nacionalismos em África. Maputo: Alcance, 2013.

NOA, F. Império, mito e miopia: Moçambique como invenção literária. Lisboa: Caminho, 2002.

PINHEIRO, V. R. Entrevista concedida à autora pelo escritor Lucílio Manjate. Maputo, 9 mar. 2017.

VIEIRA, J.L. Luuanda: estórias. São Paulo: Companhia das Letras, 2006. 


\begin{abstract}
ANEXO
Entrevista ao escritor Lucílio Manjate

Entrevistadora: Vanessa Riambau Pinheiro
\end{abstract}

A entrevista que segue foi concedida pelo escritor moçambicano Lucílio Manjate em nove de março de 2017, nas dependências da Associação dos Escritores Moçambicanos sediada em Maputo, capital de Moçambique. Tal entrevista foi realizada como atividade integrante de uma pesquisa em nível de Pós-Doutorado que se realiza na Faculdade de Letras de Lisboa.

\title{
Como foi seu percurso literário?
}

Lucílio: Meu percurso literário começa em casa. Com meu pai; com os seus livros. Eu conto muito essa história, porque é assim que começa. Lendo os livros que meu pai lia e lendo, sobretudo, a poesia de combate. Engraçado porque eu desperto para a literatura com a poesia de combate. Porque lendo-a, percebi a força interior que aquela poesia nos obrigava a produzir -vamos dizer assim -, e acho que foi este impulso que depois despertoume para o fazer literário. Então começa resumidamente assim. Começa em 1996, sim, e, dois anos depois, em 1998, eu dirijo a Associação de Escritores Moçambicanos, onde conheci os colegas de estrada, Aurélio Furdela, Sangare Okapi e outros... e continuei a escrever. Eu recordo-me que de 1996 a 2006, que é o ano em que publico meu primeiro livro, Manifesto, produto do concurso literário $\mathrm{TDM}^{13}$, uma coisa de três projetos. Que depois submeti ao TDM, eram contos. Portanto, de 1996 a 2006, tiro meu primeiro trabalho. Digamos que, em termos de escrita, no ano passado fiz vinte anos. Mas, em termos de publicação, são dez anos (de 2006 pra cá). Portanto, meu primeiro livro é de narrativas, meu primeiro livro é de contos, o Manifesto; depois tiro Os silêncios do narrador, que é uma novela, que tirei em 2010; em 2012 tiro um outro livro de contos, que é O contador de palavras; em 2013, logo a seguir, tiro uma outra novela, que é A legítima dor da Dona Sebastião e em 2016 tiro um livro infantil, que é $O$ jovem caçador e a velha dentuça. Portanto, do ponto de vista da ficção, é essa minha produção. Tenho agora dois livros que vão sair ainda este ano, um dos quais vai sair 
com o Mbate Pedro, na [Editora] Cavalo do Mar, que é $A$ triste história de Barcolino, o homem que não sabia morrer. Portanto, eu tenho estado a produzir ficção nos últimos tempos, com alguma constância, de certa forma alguma com alguma agressividade. Tento respeitar as circunstâncias de criar e de escrever que eu atravesso agora, né? Depois, coorganizei algumas antologias. Duas saíram pela Associação dos Escritores Moçambicanos, eu e outros escritores, uma é Era uma vez. A última antologia que merece algum destaque é a que organizei com Sangare Okapi - Antologia inédita: outras vozes de Moçambique, em que a gente tenta fazer uma recolha desde o momento em que se colocou um debate sobre a morte da literatura em 2003, até... recordo-me que nós organizamos essa antologia em 2011 e ela só saiu em 2015. E nós tentamos abarcar dez anos de publicação de poesia, rastreando aquilo que tinha sido publicado dez anos depois de 2003, quando surgiu o debate sobre a morte da literatura. Portanto, essa antologia saiu em 2015, ano em que também saiu um livro sobre literatura moçambicana, mas na perspectiva de um ensaio, que é Literatura moçambicana - da ameaça do esquecimento à urgência do resgate, que é uma ideia minha e dos colegas, porque todos nós falamos, já agora da contemporaneidade da literatura moçambicana. Mas nós, digamos, com esta sensibilidade que está, portanto, percebemos que há muita coisa nessa literatura, ou que é ignorada, ou que é esquecida. Então tiramos o primeiro volume livro nesse projeto, cujo intuito é, numa perspectiva comparatista, trazer, entre o passado e o presente, aquelas que nós consideramos vozes a resgatar da literatura moçambicana, que são nomes como Isaac Zita, Anibal Aleluia, o próprio Luís Bernardo Honwana, cuja obra anda um pouco, digamos, esquecida, a nível de educação, a nível, enfim, das livrarias e tudo o mais. Portanto, temos esse projeto de resgate, que é para ilustrar. São textos que, tudo bem, foram escritos em determinado tempo, mas também foram lidos de uma determinada forma. E essa forma de lê-los muita das vezes acabou confinando estes textos a um certo tipo de abordagem, quer temática, quer ideológica. O esforço que estamos a fazer agora com a ideia do resgate é mostrar e atualizar estes textos; lançar novos olhares. Portanto, digamos que o meu percurso nessa coisa que é a literatura tem essa bifurcação: por um lado, meu exercício enquanto artista; por outro, esta coisa de andar atrás daquilo que é a 
nossa literatura. Eu próprio, inclusive, estou neste momento a organizar um livro, que resulta um pouco das minhas incursões sobre a literatura moçambicana, e aí, sim, interessame olhar para a nova geração de autores moçambicanos. Terei muito gosto em partilhar quando achar que a coisa já está minimamente apresentável. Poderei partilhar consigo porque eu lanço um olhar sobre aquilo que tem sido a produção da nova geração de autores moçambicanos. Mas vendo também por uma perspectiva, digamos, dialogante, quer com a geração de Ungulani, do Mia, da Paulina, quer com a nossa geração.

\section{Você acha que há uma influência desses autores na geração de vocês?}

Lucílio: Com certeza! Há uma influência. E por isso eu trabalho no tema da memória nesse meu projeto. Que é pra mostrar que, quer do ponto de vista de abordagens temáticas, quer do ponto de vista, enfim, de questões ideológicas, quer do ponto de vista de forma, mesmo, há influências com todos os períodos que nós podemos assumir quando falamos de influência. Portanto, a influência pode ser também do meio e, se estamos todos imersos no mesmo meio, ainda que os autores apresentem elementos dialogantes, a influência pode ser sobretudo do meio. Não entre autores. Em alguns pontos é visível que este [determinando] autor foi beber do Ungulani, do Mia, do Suleiman Cassamo, enfim... eu assumo, portanto, que há influências, mas esse projeto não termina por aí, porque o que me interessa é tentar traçar o quadro que dê consistência à própria literatura moçambicana. Mostrar que estamos a construir aqui um edifício que se chama literatura moçambicana, esse trabalho da memória do sistema. Interessame, sobretudo, trazer essa geração, que durante algum tempo foi, não diria negada, mas dizia-se muito que não havia qualidade. E tal afirmação pode até ter alguma razão, porque qualidade também é uma coisa que se constrói. Refiro-me à qualidade literária. Nós zangávamos muito com estudiosos na Europa. Mas hoje eu percebo que há textos que falam por si, e começo a ver também discursos do ponto de vista de estudiosos mais abalizados nessas matérias, começo a ouvir outro tipo de pronunciamento. Portanto, isso encoraja-me, também, a trazer este projeto. Penso eu que vai poder, enfim, contribuir de alguma forma para o entendimento que nós queremos. 
Você falou algumas vezes de ideologia. Acha que essa questão é ainda premente em Moçambique?

Lucílio: Eu acho que não. Mas ela acaba parecendo uma questão de herança. Se calhar, suspeito até um pouco inconscientemente, do ponto de vista dos autores. Sendo copistas, acabam trazendo tudo o que é praga digamos dos mais velhos. Estou a recordarme agora, por exemplo, de um debate que houve, já na década de 80, na Revista Tipo, quando, penso que foi a Professora Irene Mendes, aborda o livro de Isaac Zita, Os Molwenes, e mostra que ele fez uma espécie de decalque de Luís Bernardo Honwana. E ela mostra, pra fazer os flagrantes, até. É por isso que eu digo: se do ponto de vista ideológico a coisa acaba passando, é um pouco nesse processo de aprendizagem do autor. Entende que há por um lado essa coisa. Na verdade, nessa altura, sobre o texto de Isaac Zita, depois apareceu a rebater um pouco essa ideia, mostrando que o meio também pode, mas acho que os dois têm suas razões; os dois argumentos são válidos. Mas ela parece mais um pouco até sem controle, se calhar até do que quem escreve, na medida que estamos a falar de autores que estão a começar. Ou de alguns que não são tão inexperientes assim, estamos a falar em autores que têm alguma estrada, uma estrada até maior que a minha, eu tenho 10 anos de publicação em ficção. Posso pensar num Aurélio Furdela, que já tem mais tempo, portanto ele já não escreve muito isso. Da forma que, percebo que os primeiros textos aparecem um pouco dessa forma, mas já há algumas incursões trazendo outras questões ligadas ao contemporâneo...

\section{Como se articula essa tensão entre modernidade e tradição aqui em Moçambique?}

Lucílio: Eu acho que vem e vai. Eu acho uma temática importante e que se discute. Eu não acho que é uma temática importante em si. Mas percebo que alguns autores, mesmo da minha geração, ainda olham para essa questão como princípio e fim de seus exercícios. Pessoalmente, acho que tem que ser um meio pra discutir outras questões. Pessoalmente, acho que ela ainda está presente, mas acho que há incursões importantes. A esse respeito, há um livro que vale a pena citar: A Bíblia dos pretos, de Midó das Dores. Penso que claramente a obra mostra uma nova forma de olhar pra essa relação entre tradição e modernidade. Neste livro, percebemos que entre a tradição 
e modernidade, sugere-se ali que a única coisa que nos deve guiar ou conduzir, seja lá por onde for, é a nossa capacidade de pensar, a nossa lógica, a nossa razão, é uma perspectiva mais reflexiva, sem nenhum tipo de âncora, nem nos valores tradicionais, nem nos valores modernos. Quer dizer, a bandeira ali é a bandeira do intelectual, daquele que pensa, daquele que não veste nem uma camisa nem outra. Eu percebo que aos poucos vamos saindo desse debate, que penso já ter sido muito bem escrito. Basta olhar para as obras do Ungulani Ba Ka Khosa, do Mia Couto e da Paulina Chiziane que a gente percebe isso. A impressão que eu tenho é que nós começamos a caminhar para um outro espaço, até porque esta é uma geração que tem uma potência para a internacionalização. Não que eles também não se prestem a. Mas estamos a beber outras tantas literaturas e queremos mostrar que trazemos algo novo, e trazer algo novo significa de alguma forma romper com temáticas e abordagens já cristalizadas, como é o caso.

Existem autores moçambicanos que são muito conhecidos no exterior e outros completamente desconhecidos. A que você atribui a preferência por alguns autores em detrimento de outros ou pelo menos a divulgação de alguns e não de outros? Lucílio: Esse tem sido um debate de tempos em tempos recorrente entre autores da minha geração. Uma vez eu disse aos meus amigos que a internacionalização de um escritor cabe em primeira medida ao próprio escritor. Os nomes que são chamados pra mostrar essa questão da internacionalização são nomes que produziram, têm obra feita, tem anos de estrada. Portanto, fazer literatura é, primeiro, um compromisso com a arte, e esse compromisso requer trabalho, publicação e exposição. Portanto, para mim, a primeira questão é essa. Depois, é produzindo, e produzindo com qualidade, que todo o resto vem por arrasto. Nós dizemos, por exemplo, que a crítica não fala. Mas a crítica vai falar de que se não estamos a produzir? A crítica vai lançar um olhar para quem produz. Não vai lançar um olhar para um autor que em dez anos publicou apenas um livro.É difícil fazer isso. E aqui estou a chamar um pouco da minha postura também de analista. Do ponto de vista da crítica, nós ficamos sem saber. Ok, em dez anos lançou um livro; em cinco anos lançou um livro. A gente tenta perceber o que é que se passa com esse autor, se desiste, se vai arrancar, 
se está a escrever... ainda que nasça um segundo livro, será que o traço se mantém, a mão está firme? Quer dizer, há muitas questões que são levadas, da forma que a internacionalização do autor depende de sua produção, primeiro porque é ela que vai dar o sinal para a mídia, para a crítica, enfim, para o livreiro, e vai arrastar todo esse meio. Eu olho as coisas nesses termos. É verdade que é preciso chamar atenção também dos professores de literatura, dos estudiosos de literatura, dos críticos... é preciso também dizer que a coisa está mal. $O$ autor também depende um pouco disso. Saber que eu tirei um livro, mas ele não foi bem feito, ou foi uma crítica que saiu, um olhar sobre o livro que não o abona, essas coisas todas... e isto é importante. E a crítica no mínimo isso tem que fazer: dizer o que está bom e o que está mal. Também há essa ausência. Porque a crítica também funciona para a promoção do livro. Nós sabemos que a crítica de alguma forma determina se o autor continua ou não.

Mas essa crítica, de onde vem? É de Moçambique? É de fora? Lucílio: Há muita crítica que vem de fora!

Há críticos moçambicanos também que se pronunciam? Lucílio: Há críticos moçambicanos que se pronunciam, palestras em lançamentos de livros, apresentações desses livros, nós temos isso. O que nos falta, penso, é a publicação desses textos de forma mais ou menos sistematizadas, compilar os textos e publicá-los. Esse é um dos grandes problemas.

\section{E a distribuição dos livros, como é?}

Lucílio: A distribuição é um cancro! Nós publicamos livros em Maputo. Por ser a capital, acaba sendo o centro de tudo. $\mathrm{O}$ autor moçambicano não se importa em publicar em Maputo em não sair e não ir fazer o lançamento na Beira, em Nampula. Nós sabemos que é de Maputo pra Lisboa, São Paulo, Rio de Janeiro, por aí, e já estamos satisfeitos por isso. No nosso país não há distribuição de livros. Alguma coisa grave está a acontecer agora: as livrarias estão a fechar. É um fenômeno estranho. Porque essas livrarias, há três anos, estavam abertas. Mas há uma série de livrarias a fechar. Não sei muito bem o que está a acontecer. Mas a questão da distribuição, a questão da divulgação, a questão da promoção do livro são temas que temos que debater hoje em Moçambique. Gostaria muito. 
Você acredita que haja um sistema literário moçambicano bem constituído?

Lucílio: Acredito que sim.

Mais vocacionado à prosa ou à poesia? Ou está equilibrado? Lucílio: Eu penso que está equilibrado. Nós pegamos os poetas, pegamos um poeta como o Mbate Pedro, pra quem acompanha a obra do Mbate, primeiro e segundo livros, por exemplo, no terceiro ele está fazendo outros textos. Pegamos um poeta como Sangare Okapi, pegamos um poeta como Léo Cote... a gente percebe Patraquim, Rui Knopfli, Craveirinha, quer dizer, eu acho que existe um sistema constituído. Na prosa, igualmente. Eu próprio sou produto de autores como Mia, como Ungulani Ba Ka Khosa.

E que outros autores o influenciaram, em Moçambique e fora? Lucílio: Em Moçambique, olho mais pra esses dois [últimos]. Fora, fico-me mais noslatino-americanos: Garcia Marques, Juan Julfo.Latinos são a minha praia. Mas gosto muito também do Pepetela. Gosto muito do texto dele. Basicamente é isso.

O que você acha que diferencia a literatura moçambicana de outras literaturas africanas?

Lucílio: É uma pergunta difícil. Muito difícil. Confesso que não tenho uma opinião muito bem formada. Do ponto de vista de estudos, não sou capaz realmente de responder. Mas, do ponto de vista daquilo que a gente vê, eu tenho a veleidade de dizer que penso que no quadro das nossas literaturas africanas de língua portuguesa, acho que a moçambicana, quer no ponto de vista de qualidade, quer no ponto de vista de projeção, está no bom caminho. Tem dado, embora esteja sempre presente essa questão de quem é visto, quais são os autores que vão lá pra fora, eu acho que nossa literatura tem dado sinais de renovação. Costumo brincar com os meus colegas e digo que nós temos autores de qualidade para os próximos cem anos à vontade. Estamos a falar dos jovens que são premiados, internacionalmente inclusive. E que têm mostrado trabalhos muito bons. Eu privilegio muito a literatura moçambicana quando olho para as demais literaturas. 


\section{REFERÊNCIAS}

DORES, M. das. A Bíblia dos pretos. Moçambique: Índico, 2008.

MANJATE, L. Manifesto. Moçambique: TDM, 2006.

. Os silêncios do narrador. Moçambique: AEMO, 2010.

.O contador de palavras. Moçambique: Alcance, 2012.

A legítima dor da Dona Sebastião. Moçambique:

Alcance, 2013.

2016.

.O jovem caçador e a velha dentuça. São Paulo: Kapulana,

. Literatura moçambicana - da ameaça do esquecimento à urgência do resgate. Moçambique: Alcance, 2015.

. Era Uma Vez... Moçambique. Moçambique: AEMO, 2009. .Antologia inédita - Outras Vozes de Moçambique. Moçambique: Alcance, 2014.

MENDES, I. «"A Raiva” de Isaac Zita ou "Dina” de L. B. Honwana?». In: Tempo. Maputo: Tempo Gráfica. n. 997, p. 4749, 1989.

ZITA, I. Os molwenes. Moçambique: AEMO, 1988. 


\section{Abstract \\ The exogenous conditioning and the cultural homogenization: reflections on the formation of the canon in Mozambique}

The purpose of this research is to discussthe literary canon's formation in Mozambique, investigating which processes contribute to its constitution and from which theoretical framework opine the critics who determine it. After discussing these questions who defines the canon and based on which factors -, we will attempt to analyze specific instances related to the constitution of Mozambicanity as an element of internal literary consolidation. Among them, we will verify the recurrence of themes of essentialist nature and the consequent representation of a pseudocultural homogenization practiced in the African country. In order to support our study, we will rely on the theoretical studies of Appiah (1997), Bhabha (1998), Mbembe (2014), Anderson (2008), Leite (2012, 2014) and Martinho (2001), among others.

Keywords: Canon; Literature; Mozambique. 